\title{
Production, Excretion, and Net Balance of Fixed Acid in Patients with Renal Acidosis *
}

\author{
A. David Goodman, $†$ Jacob Lemann, Jr., Edward J. Lennon, and \\ ArNold S. RELMAN $\ddagger$ \\ (From the Evans Memorial Department of Clinical Research, Massachusetts Memorial Hos- \\ pitals, and the Department of Medicine, Boston University Medical Center, Boston, \\ Mass., and the Department of Medicine, Marquette University School of \\ Medicine, Milwaukee, Wis.)
}

The processes of intermediary metabolism give rise to a number of fixed (i.e., nonvolatile) acids. It is commonly accepted that the protons released from these acids must be excreted by the kidney if acid-base equilibrium is to be maintained. $\mathrm{Pa}$ tients with various kinds of renal disease may suffer impairment of acid excretion and may develop metabolic acidosis as a consequence of the retention of endogenous acid $(1,2)$. The nature of the defect in acid excretion varies. In patients with acidosis due to severe and diffuse renal damage, reduction in the excretion of ammonium is the prime factor, and in some of them, bicarbonate wasting also plays an important role (3). In patients with the syndrome of "renal tubular acidosis," the primary defect appears to be a limitation in the capacity to lower the $\mathrm{pH}$ of the urine $(1-5)$.

One of the remarkable features of the acidosis due to renal disease is that once developed it may remain relatively stable for long periods of time. The mechanisms responsible for stabilizing the

\footnotetext{
* Submitted for publication September 1, 1964 ; accepted December 1, 1964.

Presented in part before the Association of American Physicians, May 1964.

This investigation was supported in part by a U. S. Public Health Service research career program award (K6-AM-1589) and a research grant (AM-06728) from the National Institute of Arthritis and Metabolic Diseases and by a clinical research center grant (5-MO1FR-58) from the Division of Research Facilities and Resources, National Institutes of Health.

† This work was done during tenure as a postdoctoral fellow, National Heart Institute. Present address: Department of Medicine, Albany Medical College, Albany, N. Y.

$¥$ Address requests for reprints to: Dr. Arnold S. Relman, Boston University Medical Center, 750 Harrison Ave., Boston, Mass. 02118.
}

concentration of bicarbonate in extracellular fluid have not been elucidated, but there would appear to be two general possibilities. After an initial period of acid retention, the excretion and production of acid may again become equal. This achievement of acid balance could be accomplished if the systemic acidosis either stimulated an increase in renal excretion of acid or suppressed acid production, or did both. The second possibility is that renal excretion never becomes equal to acid production, and that stabilization of extracellular bicarbonate is obtained because acidosis calls into play extrarenal mechanisms that dispose of the fraction of the endogenous acid load not excreted by the kidneys.

To examine the problem of renal acidosis in these terms it is obviously necessary to compare endogenous acid production with the excretion of acid in the urine. It has long been accepted that the net excretion of acid in the urine can be measured as the sum of urinary ammonium plus titratable acid, minus bicarbonate. Until recently, however, no method has been available for the measurement of acid production. The development in this laboratory of a technique for calculating the total endogenous acid production of subjects on a special liquid formula diet has permitted for the first time the measurement of the net external acid balance of the body $(6,7)$. In the work reported here, this balance technique has been applied to the study of renal acidosis.

The data show that, despite stable plasma bicarbonate levels, patients with severe chronic renal acidosis excrete significantly less acid in their urine than is produced by metabolic processes. However, when extracellular acidosis is corrected and plasma bicarbonate is maintained at normal levels by daily oral administration of sodium bi- 
TABLE I

Clinical data on patients with renal acidosis

\begin{tabular}{|c|c|c|c|c|c|c|c|c|}
\hline Patient & Sex & Age & Clinical diagnosis & $\begin{array}{l}\text { Creati- } \\
\text { nine } \\
\text { clear- } \\
\text { ance }\end{array}$ & BUN* & $\begin{array}{l}\text { Serum } \\
\mathrm{CO}_{2} \\
\text { content }\end{array}$ & $\begin{array}{c}\text { Known } \\
\text { duration } \\
\text { of acidosis }\end{array}$ & $\begin{array}{l}\text { Prior treatment } \\
\text { of acidosis }\end{array}$ \\
\hline & & & & $L / d a y$ & \multicolumn{3}{|c|}{$\underset{m l}{m g / 100} \underset{m m o l e s}{\mathrm{~m} /}$} & \\
\hline 1. L.S. & M & 52 & $\begin{array}{l}\text { Secondary amyloidosis of } \\
\text { kidney }\end{array}$ & 60 & 32 & 20.5 & 1 month & None \\
\hline 2. C.D. & $\mathrm{F}$ & 59 & $\begin{array}{l}\text { Renal tubular acidosis } \\
\text { Myeloma kidney? }\end{array}$ & 145 & 17 & 19.4 & 1 year & $\begin{array}{l}\text { Adequate alkali } \\
\text { for } 1 \text { year }\end{array}$ \\
\hline 3. S.E. & $\mathrm{F}$ & 57 & Chronic pyelonephritis & 36 & 47 & 18.2 & 1 year & $\begin{array}{l}\text { Adequate alkali } \\
\text { for } 1 \text { year }\end{array}$ \\
\hline 4. M.v.L. & $\mathrm{F}$ & 53 & Polycystic kidneys & 33 & 68 & 15.4 & 2 years & None \\
\hline 5. C.T. & $\mathrm{F}$ & 19 & Chronic pyelonephritis & 36 & 20 & 19.8 & $2 \frac{1}{2}$ years & None \\
\hline 6. J.J. & $\mathbf{M}$ & 46 & Chronic glomerulonephritis & 11 & 96 & 10.8 & 9 years & None \\
\hline 7. D.D. & $\mathrm{M}$ & 33 & Renal tubular acidosis & 139 & 18 & 21.5 & $5 \frac{1}{2}$ years & $\begin{array}{l}\text { Adequate alkali } \\
\text { for } 4 \frac{1}{2} \text { years }\end{array}$ \\
\hline 8. C.G. & $\mathbf{M}$ & 61 & Chronic glomerulonephritis & 15 & 84 & 16.5 & 3 months & None \\
\hline 9. J.A. & $\mathbf{M}$ & 32 & Chronic glomerulonephritis & 22 & 71 & 16.7 & 7 years & None \\
\hline 10. A.St.P. & $\mathrm{F}$ & 46 & $\begin{array}{l}\text { Renal tubular acidosis and } \\
\text { chronic pyelonephritis }\end{array}$ & 42 & 22 & 14.7 & 21 years & $\begin{array}{l}\text { Adequate alkali } \\
\text { for } 21 \text { years }\end{array}$ \\
\hline 11. P.J. & $\mathbf{M}$ & 22 & $\begin{array}{l}\text { Chronic glomerulonephritis } \\
\text { and sickle-cell anemia }\end{array}$ & 18 & 58 & 17.9 & 2 years & None \\
\hline
\end{tabular}

* Blood urea nitrogen.

† Off alkali therapy.

carbonate, net production and excretion of acid are equal and the apparent external balance of fixed acid becomes zero. These observations therefore suggest that in chronic renal failure acidosis evokes an extrarenal homeostatic mechanism that disposes of the endogenous acid not excreted in the urine.

\section{Methods}

The 18 normal subjects in this study were healthy, ambulatory, male medical students. Some pertinent clinical data concerning the 11 patients with renal acidosis are summarized in Table I. All of these patients were noted on radiologic examination to have skeletal rarefaction. No patient had significant bacteriuria during the period of study. Urinary alpha amino nitrogen was determined in the first seven patients, ${ }^{1}$ and in no instance did it exceed $83 \mathrm{mg}$ per day.

The liquid formula diet employed in these studies was identical with that previously described, the nitrogen source being a purified soy phosphoprotein virtually free of mineral ions (6). The normal subjects received 35 to 40 calories and 0.7 to $1.0 \mathrm{~g}$ protein per $\mathrm{kg}$ of body weight per day. The patients with renal disease, most of whom were relatively inactive on the wards, received 26 to 35 calories and 0.5 to $1.0 \mathrm{~g}$ protein per $\mathrm{kg}$ per day. An equimolar mixture of $\mathrm{Ca}(\mathrm{OH})_{2}$ and $\mathrm{Mg}(\mathrm{OH})_{2}$ was

\footnotetext{
${ }^{1}$ Analyses carried out through courtesy of Dr. Harry Shwaçman.
}

added to the diet in an amount calculated to equal the acid that would be generated by the metabolism of the organic phosphate present in the diet. As has been demonstrated previously, on this regimen the net production of fixed acid is measured by the sum of the urinary organic acids and urinary inorganic sulfate $(6,7)$. In the studies in which sodium bicarbonate was administered, appropriate corrections were made in the calculation of the net acid production.

Details of the acid balance technique employed in this laboratory and references to most of the analytic methods have already been published $(6,7)$. In the studies of two of the patients (C.G. and P.J.), who had marked proteinuria, it was necessary to deproteinize the urine by acidification and boiling before measuring urinary organic acids; the smaller quantities of protein excreted in the urine of the other patients did not affect the titration.

Balance studies were carried out in four patients during the development of acidosis that followed withdrawal of therapy with bicarbonate. Eight patients were studied during periods of stable acidosis, and six of these were restudied after correction of their acidosis by continuous administration of alkali.

\section{Results}

I. Acid balance during the development of renal acidosis caused by bicarbonate withdrawal. In three patients with renal acidosis (Patients 1 to 3 in Table I) the serum $\mathrm{CO}_{2}$ content and venous blood $\mathrm{pH}$ were brought to normal by the oral ad- 
ministration of sodium bicarbonate. The alkali therapy was then stopped, and acid balance studies of 6 to 7 days duration were performed as these patients became acidotic again. In one acidotic subject (Patient 4 ) observations were carried out during a 5-day period during which the serum $\mathrm{CO}_{2}$ content was spontaneously falling from an initial level of 15 mmoles per $\mathrm{L}$.

Figure 1 shows the acid balance in Patient 3 (S.E.), whose serum $\mathrm{CO}_{2}$ content fell from 26.8 to 23.1 mmoles per $\mathrm{L}$ over a period of 6 days. The net production of acid ranged from 46 to $54 \mathrm{mEq}$ per day, while the daily excretion of acid was only 23 to $29 \mathrm{mEq}$. Consequently, there was a positive balance of 21 to $30 \mathrm{mEq}$ of acid per day, as shown by the clear area under the base line. For comparison, Figure 2 shows the acid balance in a representative study of a normal subject with a stable serum $\mathrm{CO}_{2}$ content. It is apparent that despite minor daily fluctuations the cumulative acid balance was approximately zero.

As indicated in Table II, in all four patients studied during the development of acidosis the cumulative acid balance was positive, with the acid

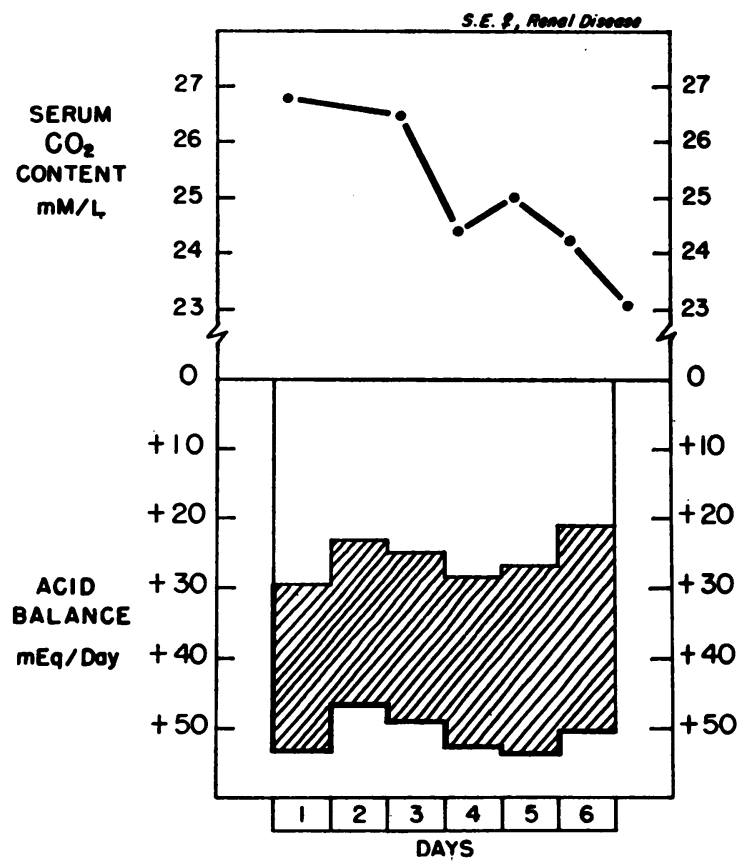

Fig. 1. Acid balance and Serum $\mathrm{CO}_{2}$ CONTENT duRING THE DEVELOPMENT OF ACIDOSIS AFTER WITHDRAWAL OF ALKALI THERAPY IN A PATIENT WITH CHRONIC RENAL DISEASE. See text for details.

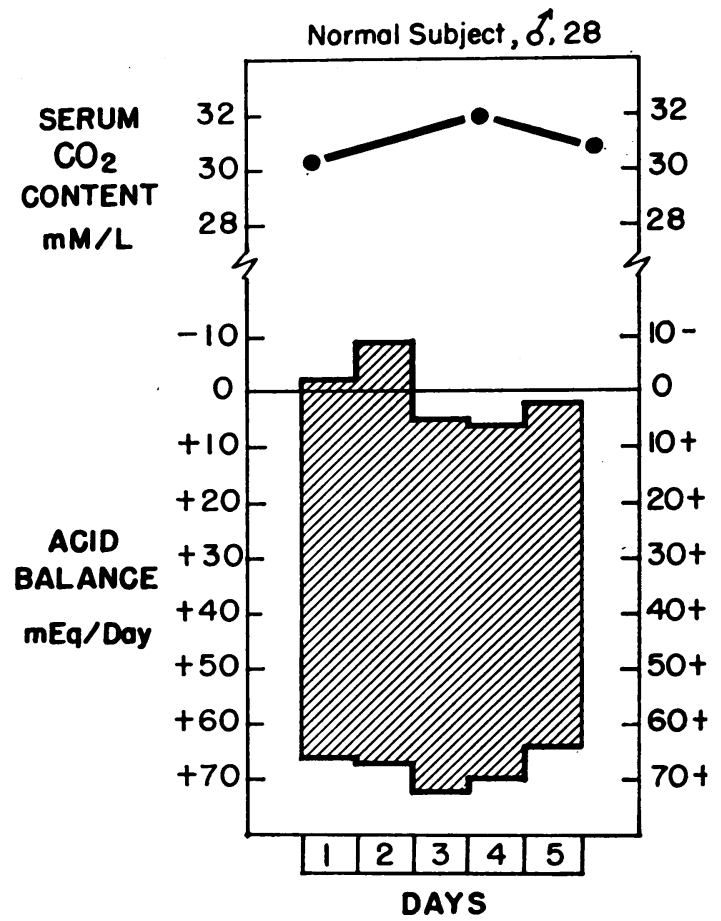

Fig. 2. ACID balance AND SERUM $\mathrm{CO}_{2}$ content in A NORMAL SUBJECT.

retention ranging from 20 to $49 \mathrm{mEq}$ per day. To determine the disposition of the retained acid within the body, the cumulative positive balance of acid was compared with the estimated decrease in total buffer content of the extracellular fluid during each study. A rough approximation of the change in extracellular content of buffer was obtained by multiplying the estimated extracellular fluid volume by the serum bicarbonate concentration at the beginning and end of the study. The initial volume was assumed to be $20 \%$ of body weight, and the final volume was calculated from the change in serum chloride and the chloride balance. As is shown in the last column of Table II, usually less than half of the retained hydrogen ion was neutralized by extracellular bicarbonate. None of these patients was edematous, but even if the initial extracellular space were as large as $30 \%$ of body weight, it can be calculated that only 50 to $70 \%$ of the retained acid would have been taken up by extracellular buffers.

II. Acid balance in stable renal acidosis. Balance studies were carried out in eight of the patients (No. 3 and 5 to 11 in Table I) during periods 
TABLE II

Acid balance during the course of the development of renal acidosis and the concomitant change in total extracellular fluid bicarbonate

\begin{tabular}{|c|c|c|c|c|c|c|c|c|c|c|c|}
\hline \multirow[b]{2}{*}{ Patient } & \multirow[b]{2}{*}{ Weight } & \multirow{2}{*}{$\begin{array}{c}\text { Days } \\
\text { of } \\
\text { study }\end{array}$} & \multirow{2}{*}{$\begin{array}{l}\text { Total } \\
\text { net } \\
\text { acid } \\
\text { produc- } \\
\text { tion }\end{array}$} & \multirow{2}{*}{$\begin{array}{l}\text { Total } \\
\text { net } \\
\text { acid } \\
\text { excre- } \\
\text { tion }\end{array}$} & \multirow{2}{*}{$\begin{array}{l}\text { Total } \\
\text { net } \\
\text { acid } \\
\text { reten- } \\
\text { tion }\end{array}$} & \multirow{2}{*}{$\begin{array}{c}\text { Mean } \\
\text { daily } \\
\text { acid } \\
\text { balance }\end{array}$} & \multicolumn{3}{|c|}{ Serum bicarbonate } & \multirow{2}{*}{$\begin{array}{l}\text { Estimated } \\
\text { change } \\
\text { in total } \\
\text { extra- } \\
\text { cellular } \\
\text { bicarbon- } \\
\text { ate* }\end{array}$} & \multirow[t]{2}{*}{$\begin{array}{c}\text { Per cent } \\
\text { of re- } \\
\text { tained } \\
\text { acid } \\
\text { buffered } \\
\text { by } \\
\text { extra- } \\
\text { cellular } \\
\text { bicar- } \\
\text { bonate }\end{array}$} \\
\hline & & & & & & & Initial & Final & Change & & \\
\hline & $k g$ & & $m E q$ & $m E q$ & $m E q$ & $m E q$ & \multicolumn{3}{|c|}{$m E q$ per $L$} & $m E q$ & $\%$ \\
\hline L.S. & 64 & 7 & 588 & 445 & +143 & +20 & 24.7 & 19.0 & -5.7 & -73 & 51 \\
\hline $\begin{array}{l}\text { C.D. } \\
\text { S.E. }\end{array}$ & $\begin{array}{l}71 \\
69\end{array}$ & $\begin{array}{l}6 \\
6\end{array}$ & $\begin{array}{l}384 \\
296\end{array}$ & $\begin{array}{r}88 \\
151\end{array}$ & $\begin{array}{l}+296 \\
+145\end{array}$ & $\begin{array}{r}+49 \\
+24\end{array}$ & $\begin{array}{l}24.0 \\
25.5\end{array}$ & $\begin{array}{l}17.3 \\
21.8\end{array}$ & $\begin{array}{l}-6.7 \\
-3.7\end{array}$ & $\begin{array}{l}-131 \\
-51\end{array}$ & $\begin{array}{l}44 \\
35\end{array}$ \\
\hline M.v.L. & 55 & 5 & 208 & 37 & +171 & +34 & 14.4 & 8.8 & -5.6 & -62 & 36 \\
\hline
\end{tabular}

* See text for details of calculation.

when their serum $\mathrm{CO}_{2}$ content and venous blood $\mathrm{pH}$ were below normal, but stable. The range of serum $\mathrm{CO}_{2}$ content for the group was 11 to 22 mmoles per L. The two patients with the most severe acidosis (No. 6 and 10) were given 15 to $30 \mathrm{mEq}$ of sodium bicarbonate daily so that the level at which their serum $\mathrm{CO}_{2}$ content stabilized would be tolerable, but the rest received no alkali during the study. Balances lasted from 4 to 10 days, after a minimum of 2 days of adaptation to the diet. The liquid diet was well tolerated; there was only one episode of vomiting. Stools were infrequent and of small volume.

Complete analytical data from one representative 6-day balance study in an acidotic patient (S.E.,
No. 3) are shown in Table III. It can be seen that there was no significant change in any of the measured substances in the serum except for unexplained fluctuation in chloride. Serum $\mathrm{CO}_{2}$ content varied between 18.1 and 19.7 mmoles per $\mathrm{L}$, and venous blood $\mathrm{pH}$ varied from 7.19 to 7.25 , without any definite directional trend in either. The excretion of those urine constituents that were determined each day was relatively steady, and the fecal excretion of sodium, potassium, and chloride was low. Body weight decreased by $0.7 \mathrm{~kg}$ during the 6 days of the study.

As shown by the data in the column headed "Endogenous acid production," the net endogenous production of fixed acids, as measured by the sum

TABLE III

Experimental data: patient

\begin{tabular}{|c|c|c|c|c|c|c|c|c|c|c|c|c|}
\hline \multirow[b]{3}{*}{ Day } & \multirow[b]{3}{*}{$\begin{array}{c}\text { Body } \\
\text { weight }\end{array}$} & \multirow{3}{*}{$\begin{array}{c}\text { Blood } \\
\text { pH }\end{array}$} & \multirow{2}{*}{\multicolumn{4}{|c|}{ Serum }} & \multicolumn{6}{|c|}{ Urine } \\
\hline & & & & & & & & & & & Inor- & \\
\hline & & & $\begin{array}{l}\text { Total } \\
\mathrm{CO}_{2}\end{array}$ & $\mathrm{Na}$ & $\mathbf{K}$ & $\mathrm{Cl}$ & $\mathrm{pH}$ & T.A.† & $\mathrm{NH}_{4}$ & $\begin{array}{r}\text { "Net } \\
\text { acid" } \ddagger\end{array}$ & $\begin{array}{c}\text { ganic } \\
\mathrm{SO}_{4}\end{array}$ & $\begin{array}{c}\text { Organic } \\
\text { acids }\end{array}$ \\
\hline \multicolumn{3}{|c|}{$k g$} & mmoles $/ L$ & \multicolumn{3}{|c|}{$m E q / L$} & \multicolumn{6}{|c|}{$m E q / d a y$} \\
\hline 1 & 70.74 & 7.23 & 18.2 & 144 & 5.1 & 119 & 5.09 & 19 & 32 & 51 & 36 & 29 \\
\hline 2 & 70.29 & 7.24 & 18.9 & & & 117 & 5.15 & 15 & 33 & 48 & 34 & 26 \\
\hline 3 & 70.20 & 7.21 & 19.7 & & & & 5.12 & 14 & 34 & 48 & 36 & 25 \\
\hline 4 & 70.74 & 7.23 & 18.3 & & & 119 & 5.18 & 15 & 38 & 53 & 42 & 28 \\
\hline 5 & 70.66 & 7.25 & 18.2 & 142 & 4.6 & & 5.20 & 14 & 38 & 52 & 40 & 30 \\
\hline 6 & 70.29 & 7.19 & 18.3 & & & 113 & 5.20 & 14 & 51 & 65 & 42 & 32 \\
\hline 7 & 70.06 & 7.19 & 18.1 & 143 & 4.5 & & & & & & & \\
\hline
\end{tabular}

* Basic diet per day: Na, $89 \mathrm{mEq} ; \mathrm{K}, 62 \mathrm{mEq} ; \mathrm{Cl}, 145 \mathrm{mEq} ; \mathrm{Ca}, 10.5 \mathrm{mEq} ; \mathrm{P}, 9.9 \mathrm{mmoles} ; \mathrm{N}, 9.4 \mathrm{~g}$.

$\dagger$ Titratable acidity.

$\ddagger \mathrm{NH}_{4}+$ T.A. $-\mathrm{HCO}_{3}$.

$\$$ Inorganic $\mathrm{SO}_{4}+$ organic acids.

"Acid production - "net acid."

T Based on the analysis of a pooled specimen. 
of urinary inorganic sulfate plus organic acids, ranged from 60 to $74 \mathrm{mEq}$ per day. By contrast, the "net acid" excretion (ammonium plus titratable acid minus bicarbonate) was only 48 to $65 \mathrm{mEq}$ per day. On every day of the study the production of fixed acid therefore exceeded its excretion by 9 to $18 \mathrm{mEq}$ (mean : $+14 \mathrm{mEq}$ per day) as shown in the column headed "Acid balance." There was a total retention of $83 \mathrm{mEq}$ of acid, but despite this the serum $\mathrm{CO}_{2}$ content remained constant.

Figure 3 illustrates the acid balance data in another acidotic subject (P.J., No. 11), who demonstrated an even more striking retention of acid. As shown in the Figure, net acid production varied from 47 to $53 \mathrm{mEq}$ per day, but acid excretion was only 17 to $21 \mathrm{mEq}$ per day. The daily positive balance, as represented by the clear area below the zero line, averaged $32 \mathrm{mEq}$. Despite a total retention of $159 \mathrm{mEq}$ of acid over the 5 days of study, the serum $\mathrm{CO}_{2}$ content remained unchanged.

The data on acid balance in all eight patients studied while in acidosis are summarized in Table IV. In these patients, daily net acid production exceeded daily net acid excretion by 12 to 32 $\mathrm{mEq}$, with a mean positive balance of $19 \pm 7$ (SD) $\mathrm{mEq}$ per day. Expressed as a percentage of the net acid production, the mean positive balance was $+41 \pm 18 \%$. The three columns on the right in Table IV show the observed changes in

\section{P. J. 022 Chronic Glomerulonephritis}
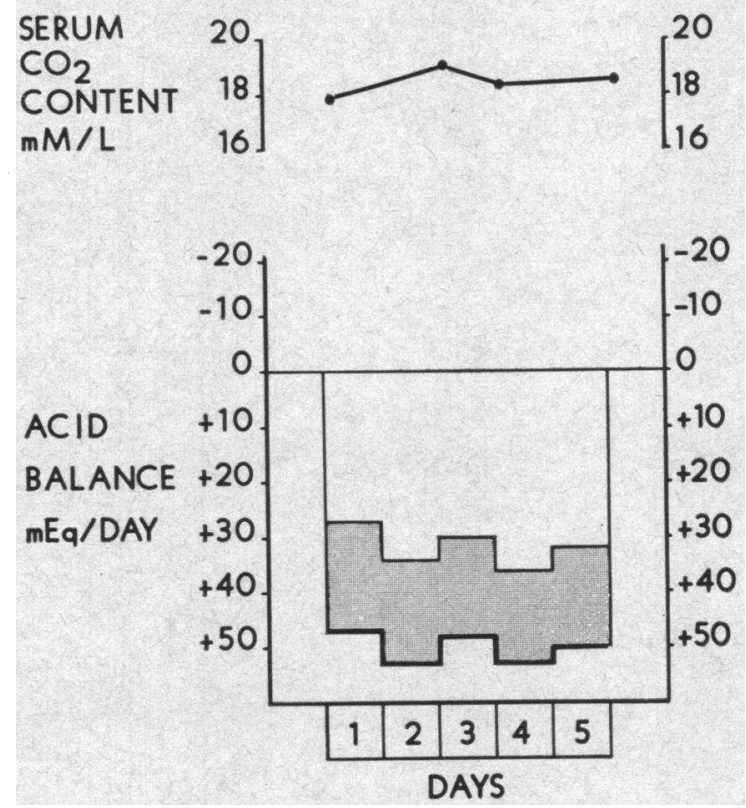

Fig. 3. Acid balance and serum $\mathrm{CO}_{2}$ content in a PATIENT WITH CHRONIC, STABLE RENAI ACIDOSIS.

serum $\mathrm{CO}_{2}$ content. It is obvious that there was no significant change in any instance, and the mean difference between the initial and final $\mathrm{CO}_{2}$ values was only $+0.2 \pm 0.8$ mmoles per $L$.

For comparison, in the lower part of Table IV are summarized the relevant data obtained from 27

TABLE III

S.E., stable acidosis*

\begin{tabular}{|c|c|c|c|c|c|c|c|c|c|c|c|c|c|}
\hline \multirow{2}{*}{$\begin{array}{l}\text { Endog- } \\
\text { enous } \\
\text { acid } \\
\text { produc- } \\
\text { tion§ }\end{array}$} & \multirow{2}{*}{$\underset{\text { balance } \|}{\text { Acid }}$} & \multicolumn{6}{|c|}{ Urine } & \multicolumn{6}{|c|}{ Stool } \\
\hline & & $\mathrm{Na}$ & $\mathbf{K}$ & $\mathrm{Ca}$ & $\mathrm{Cl}$ & $\mathbf{P}$ & $\mathbf{N}$ & $\mathrm{Na}$ & $\mathbf{K}$ & $\mathrm{Ca}$ & $\mathrm{Cl}$ & $\mathbf{P}$ & $\mathrm{N}$ \\
\hline \multicolumn{2}{|c|}{$m E q / d a y$} & \multicolumn{4}{|c|}{$m E q / d a y$} & $\begin{array}{c}\text { mmoles/ } \\
\text { day }\end{array}$ & $g / d a y$ & \multicolumn{4}{|c|}{$m E q / d a y$} & $\underset{\text { day }}{\text { mmoles/ }}$ & $g / d a y$ \\
\hline 65 & +14 & $99 \pi$ & $84 \pi$ & 4.0 & 167 I & 11.6 & $11.8 \mathrm{~T}$ & 1 & 6 & 27 & 1 & 12 & 0.5 \\
\hline 60 & +12 & 99 & 84 & 4.0 & 167 & 8.4 & 11.8 & 1 & 6 & 27 & 1 & 12 & 0.5 \\
\hline 61 & +13 & 99 & 84 & 4.3 & 167 & 7.5 & 11.8 & 1 & 6 & 27 & 1 & 12 & 0.5 \\
\hline 70 & +17 & 99 & 84 & 5.4 & 167 & 7.6 & 11.8 & 1 & 6 & 27 & 1 & 12 & 0.5 \\
\hline 70 & +18 & 99 & 84 & 5.0 & 167 & 7.7 & 11.8 & 1 & 6 & 27 & 1 & 12 & 0.5 \\
\hline 74 & +9 & 99 & 84 & 4.8 & 167 & 7.9 & 11.8 & 1 & 6 & 27 & 1 & 12 & 0.5 \\
\hline
\end{tabular}




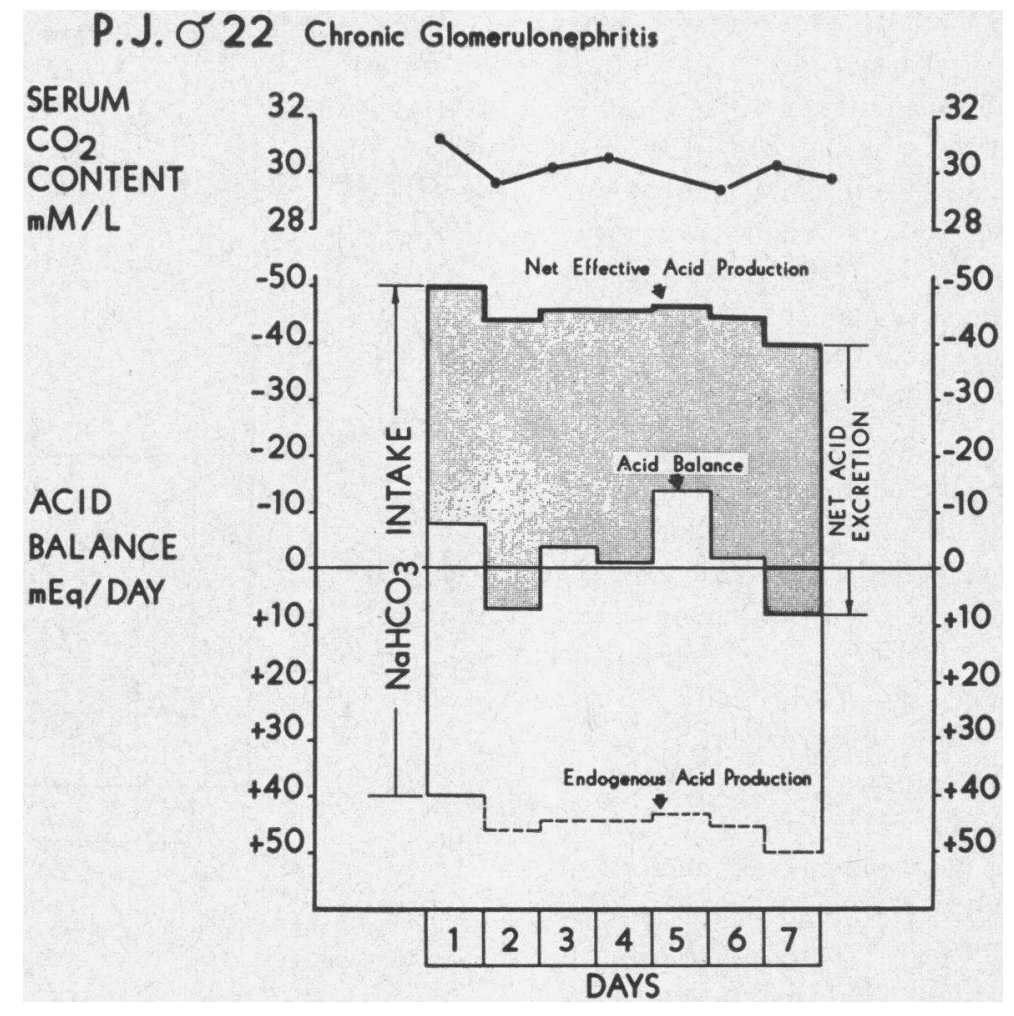

Fig. 4. ACId Balance ANd SERUM $\mathrm{CO}_{2}$ CONTENT IN THE PATIENT SHOWN in Figure 3, AFTer acidosis had BEEN CORRECTED AND WHILE A NORMAL $\mathrm{CO}_{2}$ CONTENT WAS MAINTAINED BY DAILY ADMINISTRATION OF $\mathrm{NAHCO}_{3}$. See text for explanations.

studies in 18 normal subjects whose serum $\mathrm{CO}_{2}$ content was normal and stable. As has been previously observed (6) acid production and acid excretion are essentially equal, as reflected by the fact that the mean daily balance was zero. The difference between the mean daily balance in the normal subjects and the acidotic patients was highly significant $(\mathrm{p}<.001)$.

III. Acid balance during the treatment of renal acidosis with sodium bicarbonate. Six of the eight patients described above were subsequently restudied after their serum $\mathrm{CO}_{2}$ content and venous blood $\mathrm{pH}$ had been restored to normal levels by the administration of sodium bicarbonate. Acid balances were carried out for 7 to 9 days while the serum $\mathrm{CO}_{2}$ content was held constant and normal by the daily use of sodium bicarbonate.

Complete analytical data from one such study lasting 7 days are shown in Table V. The subject of this balance (S.E., No. 3) was also studied while acidotic (Table III). As in the first study, serum electrolyte concentrations were relatively steady. Serum $\mathrm{CO}_{2}$ content varied between 25.1 and 27.6 mmoles per $L$, and venous blood $\mathrm{pH}$ varied from 7.33 to 7.37 , with no definite directional trend in either. The excretion of those urine constituents that were measured daily was relatively steady. The fecal excretion of sodium, potassium, and chloride was low and was not significantly different from that during the balance shown in Table III. Body weight decreased by $1.1 \mathrm{~kg}$.

Endogenous acid production was relatively steady and was slightly less than that observed when the patient had been acidotic. Because of the considerable loss of bicarbonate in the urine, the amount of sodium bicarbonate required to maintain the serum $\mathrm{CO}_{2}$ content at a normal level exceeded the net endogenous acid production each day. Thus, the net effective acid load (endogenous acid production minus administered bicarbonate) was negative. Furthermore, since the 
TABLE IV

Acid balance in patients with stable renal acidosis compared to that in normal subjects

\begin{tabular}{|c|c|c|c|c|c|c|c|c|}
\hline \multirow[b]{2}{*}{ Patient } & \multirow{2}{*}{$\begin{array}{l}\text { Days } \\
\text { of } \\
\text { study }\end{array}$} & \multirow{2}{*}{$\begin{array}{l}\text { Mean } \\
\text { daily } \\
\text { net } \\
\text { acid } \\
\text { produc- } \\
\text { tion }\end{array}$} & \multirow{2}{*}{$\begin{array}{l}\text { Mean } \\
\text { daily } \\
\text { net } \\
\text { acid } \\
\text { excre- } \\
\text { tion }\end{array}$} & \multirow{2}{*}{$\begin{array}{c}\text { Mean daily } \\
\text { acid balance }\end{array}$} & \multirow{2}{*}{$\begin{array}{l}\text { Mean daily acid } \\
\text { balance as a per } \\
\text { cent of mean } \\
\text { daily acid pro- } \\
\text { duction }\end{array}$} & \multicolumn{3}{|c|}{ Serum $\mathrm{CO}_{2}$ content } \\
\hline & & & & & & Initial & Final & Change \\
\hline & & $m E q$ & $m E q$ & $m E q$ & & & mmoles $/ L$ & \\
\hline $\begin{array}{l}\text { S.E. } \\
\text { C.T. } \\
\text { J.J. } \\
\text { D.D. } \\
\text { C.G. } \\
\text { J.A. } \\
\text { A.St.P. } \\
\text { P.J. }\end{array}$ & $\begin{array}{r}6 \\
10 \\
4 \\
9 \\
7 \\
6 \\
7 \\
5\end{array}$ & $\begin{array}{l}67 \\
46 \\
39 \\
70 \\
39 \\
54 \\
37 \\
50\end{array}$ & $\begin{array}{l}53 \\
26 \\
19 \\
54 \\
27 \\
40 \\
12 \\
18\end{array}$ & $\begin{array}{l}+14 \\
+20 \\
+20 \\
+16 \\
+12 \\
+14 \\
+25 \\
+32\end{array}$ & $\begin{array}{l}+21 \\
+43 \\
+52 \\
+23 \\
+31 \\
+26 \\
+66 \\
+63\end{array}$ & $\begin{array}{l}18.2 \\
19.8 \\
10.8 \\
21.5 \\
16.5 \\
16.7 \\
14.7 \\
17.9\end{array}$ & $\begin{array}{l}18.1 \\
18.8 \\
10.1 \\
21.6 \\
17.3 \\
18.3 \\
14.8 \\
18.5\end{array}$ & $\begin{array}{l}-0.1 \\
-1.0 \\
-0.7 \\
+0.1 \\
+0.8 \\
+1.6 \\
+0.1 \\
+0.6\end{array}$ \\
\hline $\begin{array}{l}\text { Mean of } 8 \\
\text { patients with } \\
\text { renal acidosis } \\
\pm \mathrm{SD}\end{array}$ & 7 & & & $+19 \pm 7$ & $+41 \pm 18 \%$ & $17.0 \pm 3.3$ & $17.2 \pm 3.4$ & $\pm 0.2 \pm 0.8$ \\
\hline $\begin{array}{l}\text { Mean of } 27 \\
\text { studies in } 18 \\
\text { normal subjects } \\
\pm \mathrm{SD}\end{array}$ & 5 & & & $\begin{array}{r}0 \pm 7 \\
p<0.001\end{array}$ & $\begin{array}{r}0 \pm 9 \% \\
\mathrm{p}<0.001\end{array}$ & $29.7 \pm 1.7$ & $28.9 \pm 2.1$ & $-0.8 \pm 1.8$ \\
\hline
\end{tabular}

daily excretion of bicarbonate exceeded the excretion of titratable acid plus ammonium, the net excretion of acid $\left(\mathrm{NH}_{4}+\right.$ T.A. $\left.-\mathrm{HCO}_{3}\right)$ was also negative. When the net effective acid load was more negative than the net acid excretion, as on days $1,3,4$, and 6 , the acid balance was negative. When the net effective acid load was less negative than the net acid excretion, as on days 2,5 , and 7 , the acid balance was positive. The mean daily balance for the entire study was $-3 \mathrm{mEq}$, as compared with $+14 \mathrm{mEq}$ for the previous study when the patient was acidotic (Table III).

The data on acid balance in another patient (P.J., No. 11), whose serum $\mathrm{CO}_{2}$ content was also maintained at normal levels, are plotted in Figure 4. Data obtained from this patient while he was acidotic were shown previously in Figure 3. Net endogenous acid production was nearly the same as in the previous study of this patient, and is indicated by the lower dotted line in Figure 4. In this study, as in the study shown in Table III, the net effective acid load was negative, because of the administration of large amounts of sodium bicarbonate. For instance, on day 1 the endogenous acid production was $40 \mathrm{mEq}$, but 90 $\mathrm{mEq}$ of sodium bicarbonate was administered, and thus the net effective acid load was $-50 \mathrm{mEq}$.
Consequently, the net effective acid load is plotted upwards (in the negative direction) from the zero line and is shown by the heavy continuous line at the top. Since the net acid excretion was also negative, this quantity is plotted as a shaded column back towards the base line, starting from the level of the net effective acid production.

Figure 4 shows that the acid balance was negative on days $1,3,4,5$, and 6 (as indicated by the failure of the shaded columns to reach the zero line). The mean daily balance during the study was $-2 \mathrm{mEq}$. The data plotted here contrast sharply with the persistently positive balance (mean $+32 \mathrm{mEq}$ per day) observed in the same patient when he was acidotic, as shown in Figure 3.

Table VI summarizes the data on the acid balance in all six of the patients who were studied after correction of acidosis. The mean daily balance in individual subjects ranged from +2 to $-20 \mathrm{mEq}$ per day; the mean for the group was $-4 \pm 10 \mathrm{mEq}$ per day, which does not differ significantly from the mean balance in normal subjects $(0 \pm 7.0 \mathrm{mEq}$ per day). As shown in the right-hand columns of the Table, serum $\mathrm{CO}_{2}$ content was within normal limits in each patient and remained relatively constant during the study. 
TABLE V

Experimental data: patient

\begin{tabular}{|c|c|c|c|c|c|c|c|c|c|c|c|c|c|c|}
\hline \multirow[b]{2}{*}{ Day } & \multirow[b]{2}{*}{$\begin{array}{c}\text { Body } \\
\text { weight }\end{array}$} & \multirow[b]{2}{*}{$\begin{array}{c}\text { Blood } \\
\text { pH }\end{array}$} & \multicolumn{4}{|c|}{ Serum } & \multicolumn{7}{|c|}{ Urine } & \multirow{2}{*}{$\begin{array}{l}\text { Endog. } \\
\text { acid } \\
\text { prod.8 }\end{array}$} \\
\hline & & & $\begin{array}{c}\text { Total } \\
\mathrm{CO}_{2}\end{array}$ & $\mathrm{Na}$ & $\mathbf{K}$ & $\mathrm{Cl}$ & $\mathrm{pH}$ & $\begin{array}{l}\text { Total } \\
\mathrm{CO}_{2}\end{array}$ & T.A.† & $\mathrm{NH}_{4}$ & $\begin{array}{l}\text { "Net } \\
\text { acid"† }\end{array}$ & $\underset{\mathrm{SO}_{4}}{\text { Inorg. }}$ & $\begin{array}{l}\text { Org. } \\
\text { acids }\end{array}$ & \\
\hline & $\mathrm{kg}$ & & mmoles $/ L$ & & $m E q / L$ & & & mmoles $/ 1$ & & & $m E q / d a y$ & & & $\underset{d a y}{m E q /}$ \\
\hline 1 & 72.33 & 7.33 & 26.8 & & & & 7.31 & 32 & 1 & 2 & -27 & 30 & 24 & 54 \\
\hline 2 & 72.33 & & 25.3 & & & & 7.28 & 37 & 1 & 3 & -32 & 35 & 30 & 65 \\
\hline 3 & 71.87 & 7.37 & 26.3 & 140 & 5.7 & 109 & 7.20 & 31 & 1 & 2 & -26 & 30 & 24 & 54 \\
\hline 4 & 71.87 & & 27.3 & & & & 7.22 & 32 & 1 & 2 & -26 & 35 & 30 & 65 \\
\hline 5 & 71.87 & 7.34 & 27.6 & & & & 7.24 & 32 & 1 & 2 & -26 & 32 & 27 & 59 \\
\hline 6 & 71.76 & & 27.2 & 140 & 4.6 & 108 & 7.14 & 32 & 1 & 3 & -25 & 30 & 26 & 56 \\
\hline 7 & 71.42 & 7.33 & 27.5 & & & & 6.80 & 21 & 4 & 14 & -10 & 28 & 29 & 57 \\
\hline 8 & 71.20 & 7.35 & 25.1 & & & & & & & & & & & \\
\hline
\end{tabular}

* Basic diet per day: $\mathrm{K}, 61 \mathrm{mEq} ; \mathrm{Ca}, 9.9 \mathrm{mEq} ; \mathrm{Cl}, 88 \mathrm{mEq} ; \mathrm{P}, 8.2 \mathrm{mmoles} ; \mathrm{N}, 8.4 \mathrm{~g}$. Because of variation in alkali fed ( $\mathrm{NaHCO}$ ) the $\mathrm{Na}$ intake was: days 1 to $4,126 \mathrm{mEq}$; days 5 and $6,114 \mathrm{mEq}$; and day $7,90 \mathrm{mEq}$.

t Titratable acidity.

$+\mathrm{NH}_{4}+$ T.A. $-\mathrm{HCO}$.

Inorganic $\mathrm{SO}_{4}+$ organic acids.

Acid production minus alkali fed.

Net effective acid productlon minus "net acid."

Based on the analysis of a pooled specimen.

The results of these studies become more meaningful when the daily acid balance in each patient after correction of acidosis is directly compared with the balance in the same patient when acidotic. Table VII shows that in five of the six patients the average daily balance was significantly less positive after correction of the acidosis. The mean daily balance for this group of patients after correction $(-4 \pm 10 \mathrm{mEq})$ is significantly different from the mean balance in these same six patients during acidosis $(+22 \pm 7 \mathrm{mEq})(\mathrm{p}<$ $.001)$.

IV. Acid production. The eight patients with renal disease produced $1.05 \pm .20$ (SD) $\mathrm{mEq}$ of endogenous acid per $\mathrm{kg}$ of body weight while they were acidotic, and in the six who were restudied when their serum $\mathrm{CO}_{2}$ content was normal, acid production was $1.02 \pm 0.23 \mathrm{mEq}$. Normal controls, fed essentially the same diet per unit weight, produced $0.93 \pm 0.13 \mathrm{mEq}$ per $\mathrm{kg}$. Thus, neither

TABLE VI

Acid balance after the correction of renal acidosis compared to that in normal subjects

\begin{tabular}{|c|c|c|c|c|c|c|c|}
\hline \multirow[b]{2}{*}{ Patient } & \multirow{2}{*}{$\begin{array}{c}\text { Days } \\
\text { of } \\
\text { study }\end{array}$} & \multirow{2}{*}{$\begin{array}{c}\text { Mean } \\
\text { daily net } \\
\text { effective } \\
\text { acid } \\
\text { production* }\end{array}$} & \multirow{2}{*}{$\begin{array}{c}\text { Mean } \\
\text { daily net } \\
\text { acid } \\
\text { excretion }\end{array}$} & \multirow{2}{*}{$\begin{array}{l}\text { Mean daily } \\
\text { acid balance }\end{array}$} & \multicolumn{3}{|c|}{ Serum $\mathrm{CO}_{2}$ content } \\
\hline & & & & & Initial & Final & Change \\
\hline & & $m E q$ & $m E q$ & $m E q$ & & mmoles $/ L$ & \\
\hline $\begin{array}{l}\text { J.J. } \\
\text { D.D. } \\
\text { J.A. } \\
\text { A.St.P. } \\
\text { P.J. } \\
\text { S.E. }\end{array}$ & $\begin{array}{l}8 \\
9 \\
7 \\
7 \\
7 \\
7\end{array}$ & $\begin{array}{l}-90 \\
-27 \\
-27 \\
-99 \\
-45 \\
-28\end{array}$ & $\begin{array}{l}-70 \\
-37 \\
-19 \\
-101 \\
-43 \\
-25\end{array}$ & $\begin{array}{l}-20 \\
+10 \\
-8 \\
+2 \\
-2 \\
-3\end{array}$ & $\begin{array}{l}27.1 \\
26.6 \\
26.7 \\
27.1 \\
31.2 \\
26.8\end{array}$ & $\begin{array}{l}26.6 \\
24.7 \\
25.3 \\
27.2 \\
29.9 \\
25.1\end{array}$ & $\begin{array}{l}-0.5 \\
-1.9 \\
-1.4 \\
+0.1 \\
-1.3 \\
-1.7\end{array}$ \\
\hline $\begin{array}{l}\text { Mean of } 6 \text { patients } \\
\text { after correction } \\
\text { of renal acidosis } \\
\pm \mathrm{SD}\end{array}$ & & & & $\begin{array}{l}-4 \\
\pm 10\end{array}$ & $\begin{array}{r}27.6 \\
\pm 1.8\end{array}$ & $\begin{array}{r}26.5 \\
\pm 1.9\end{array}$ & $\begin{array}{l}-1.1 \\
\pm 0.8\end{array}$ \\
\hline $\begin{array}{l}\text { Mean of } 27 \text { studies } \\
\text { in } 18 \text { normal subjects } \\
\pm \mathrm{SD}\end{array}$ & & & & $\begin{array}{rl} & 0 \\
& \\
\mathrm{p} & 7 \\
> & 0.2\end{array}$ & & & \\
\hline
\end{tabular}

* Measured endogenous acid production minus $\mathrm{HCO}_{3}-$ administered. 
TABLE $V$

S.E., stable acidosis*

\begin{tabular}{|c|c|c|c|c|c|c|c|c|c|c|c|c|c|c|}
\hline \multirow{2}{*}{$\underset{\text { fed }}{\text { Alkali }}$} & \multirow{2}{*}{$\begin{array}{l}\text { Net ef- } \\
\text { fective } \\
\text { acid } \\
\text { prod.\| }\end{array}$} & \multirow{2}{*}{$\underset{\text { balance }}{\text { Acid }}$} & \multicolumn{6}{|c|}{ Urine } & \multicolumn{6}{|c|}{ Stool** } \\
\hline & & & $\overline{\mathrm{Na}}$ & $\mathbf{K}$ & $\mathrm{Ca}$ & $\mathrm{Cl}$ & $\mathbf{P}$ & $\mathbf{N}$ & $\mathrm{Na}$ & $\mathbf{K}$ & $\mathrm{Ca}$ & $\mathrm{Cl}$ & $\mathbf{P}$ & $\mathbf{N}$ \\
\hline$\underset{d a y}{m E q /}$ & $\underset{d a y}{m E q /}$ & $\underset{d a y}{m E q /}$ & \multicolumn{4}{|c|}{$m E q / d a y$} & $\begin{array}{c}\text { mmoles/ } \\
\text { day }\end{array}$ & $g / d a y$ & \multicolumn{4}{|c|}{$m E q / d a y$} & $\begin{array}{c}\text { mmoles/ } \\
\text { day }\end{array}$ & $g / d a y$ \\
\hline 95 & -41 & -14 & $105^{* *}$ & $60^{* *}$ & $0.9 * *$ & $77 * *$ & $7.9 * *$ & $9.9 * *$ & 1 & 9 & 28 & 1 & 15.4 & 0.8 \\
\hline 95 & -30 & +2 & 105 & 60 & 0.9 & 77 & 7.9 & 9.9 & 1 & 9 & 28 & 1 & 15.4 & 0.8 \\
\hline 95 & -41 & -15 & 105 & 60 & 0.9 & 77 & 7.9 & 9.9 & 1 & 9 & 28 & 1 & 15.4 & 0.8 \\
\hline 95 & -30 & -4 & 105 & 60 & 0.9 & 77 & 7.9 & 9.9 & 1 & 9 & 28 & 1 & 15.4 & 0.8 \\
\hline 83 & -24 & +2 & 105 & 60 & 0.9 & 77 & 7.9 & 9.9 & 1 & 9 & 28 & 1 & 15.4 & 0.8 \\
\hline 83 & -27 & -2 & 105 & 60 & 0.9 & 77 & 7.9 & 9.9 & 1 & 9 & 28 & 1 & 15.4 & 0.8 \\
\hline 59 & -2 & +8 & 105 & 60 & 0.9 & 77 & 7.9 & 9.9 & 1 & 9 & 28 & 1 & 15.4 & 0.8 \\
\hline
\end{tabular}

renal disease itself nor the presence of acidosis seemed to have a marked influence on the endogenous acid production. Stabilization of the plasma bicarbonate in the acidotic state clearly was not due in any measure to a compensatory reduction in acid production.

V. Electrolyte and nitrogen balance, and stool composition. Table VIII summarizes the data on weight changes and the balances of sodium, potassium, chloride, and nitrogen. None of these balances was significantly different from zero, and there were no significant differences between normals and patients with renal disease. Furthermore, correction of acidosis had no definite effect. There was some tendency for weight loss in the patients, but there was no significant difference between acidosis and the corrected state.

Fecal excretion of sodium, potassium, and chloride was low. There was less than $2 \mathrm{mEq}$ per day of sodium, less than $10 \mathrm{mEq}$ per day of potassium, and less than $2 \mathrm{mEq}$ per day of chloride in all of the studies on the patients. As exemplified in the data of Tables III and V, correction of acidosis had no significant effect on the fecal content of these elements.

Because of the brevity of the balance studies and the scantiness of the stools, no meaningful data on fecal content or balances of calcium and phosphorus could be obtained.

\section{Discussion}

The present observations indicate that the development of renal acidosis is a consequence of the retention of endogenous acid. As would be expected, each of the four patients who was studied while his serum $\mathrm{CO}_{2}$ content was falling showed a strongly positive acid balance, which was more than adequate to account for the observed fall in extracellular bicarbonate.

Much more remarkable, however, was the discovery that patients with stable renal acidosis also do not excrete all of their daily endogenous acid load in the urine. Each of eight such patients was found to be in positive acid balance, on the average retaining approximately a third of the endogenously produced acid. Furthermore, when the acidosis was completely corrected in six of these

TABLE VII

Acid balance before and after the correction of renal acidosis

\begin{tabular}{lccc}
\hline \hline & $\begin{array}{c}\text { Mean daily } \\
\text { acid balance } \\
\text { during } \\
\text { acidosis }\end{array}$ & $\begin{array}{c}\text { Mean daily } \\
\text { acid balance } \\
\text { after cor- } \\
\text { rection of } \\
\text { acidosis }\end{array}$ & p \\
\hline Patient & $m E q$ & $m E q$ & \\
J.J. & $+20 \pm 5$ & $-20 \pm 16$ & $<0.001$ \\
D.D. & $+16 \pm 5$ & $+10 \pm 8$ & $>0.05$ \\
J.A. & $+14 \pm 2$ & $-8 \pm 16$ & $<0.01$ \\
A.St.P. & $+25 \pm 11$ & $+2 \pm 10$ & $<0.001$ \\
P.J. & $+32 \pm 4$ & $-2 \pm 8$ & $<0.001$ \\
S.E. & $+14 \pm 3$ & $-3 \pm 8$ & $<0.001$ \\
Mean \pm SD & $+22 \pm 7$ & $-4 \pm 10$ & $<0.001$ \\
\hline
\end{tabular}


TABLE VIII

Weight changes and electrolyte and nitrogen balances*

\begin{tabular}{|c|c|c|c|c|c|}
\hline Subjects & Weight change & Sodium & Chloride & Potassium & Nitrogen \\
\hline & $\mathrm{kg} / d a y$ & $m E q / d a y$ & $m E q / d a y$ & $m E q / d a y$ & $g / d a y$ \\
\hline Renal acidosis & $-0.20 \pm 0.1$ & $+4 \underset{(8)}{ \pm} 21$ & $+\underset{(8)}{+13 \pm 29}$ & $-9 \pm \underset{(8)}{ \pm} 15$ & $-1.4 \pm 2.1$ \\
\hline Corrected renal acidosis & $\begin{array}{c}-0.15 \pm 0.07 \\
(6)\end{array}$ & $+2 \underset{(6)}{ \pm} 17$ & $\begin{array}{c}0 \pm 11 \\
(6)\end{array}$ & $-3 \pm 6$ & $-0.4 \pm 2.0$ \\
\hline Normals & $\begin{array}{c}-0.05 \pm 0.1 \\
(27)\end{array}$ & $\begin{array}{c}+8 \pm 14 \\
(24)\end{array}$ & $\begin{array}{c}+14 \pm 14 \\
(24)\end{array}$ & $\begin{array}{c}-2 \pm 9 \\
(24)\end{array}$ & $\begin{array}{c}+0.2 \pm 0.3 \\
\text { (3) }\end{array}$ \\
\hline
\end{tabular}

* All data given as mean \pm standard deviation. The number of studies is given in parentheses.

patients, there was a significant reversal of the balance in five, and the mean balance for the group was essentially the same as that of the normal control subjects. These observations point to the crucial role of acidosis in the production of the positive acid balance noted before treatment with alkali.

Despite the persistently positive balance of acid in the acidotic patients, serum $\mathrm{CO}_{2}$ content and blood $\mathrm{pH}$ remained remarkably constant. Progressive contraction of the extracellular space could not have played a role in stabilizing the serum $\mathrm{CO}_{2}$ content because of the magnitude of the contraction that would have been necessary; furthermore, the absence of a negative chloride balance and of any large change in serum chloride argues against the occurrence of significant change in the chloride space. It follows, therefore, that the total extracellular store of bicarbonate remained relatively constant.

The stability of extracellular bicarbonate stores in the face of a persistently positive acid balance indicates that the endogenous acid not excreted in the urine must either have been excreted by some other route or neutralized within the body by some base other than extracellular bicarbonate. Since no normal extrarenal route of fixed acid excretion is known, it would appear most likely that acid is continuously neutralized by base derived from tissues. In view of the fact that retention of acid might continue for months or years in patients with chronic renal acidosis, the tissue providing this base would need to have a large supply of alkali that could be liberated at a very slow rate. These considerations point toward bone as the source of the endogenous base.

Many years ago Albright and Reifenstein clearly recognized that demineralization of the skeleton could release alkali (8). Using their estimate of the amount of alkali released when bone salts are dissolved at $\mathrm{pH} 7.4$, we can calculate that the adult skeleton contains approximately $35,000 \mathrm{mEq}$ of potentially available base, a quantity that would be adequate to neutralize the acid retained in the present studies for a period of several years. Because of the limited reactive surface of mature bone, only a small fraction of its mineral salts would be available for interaction with acid at any one time; this could account for the slow continuous release of alkali in the face of a constant extracellular fluid $\mathrm{pH}$. By contrast, the buffers in extracellular fluid and soft tissues neutralize acid only when $\mathrm{pH}$ is falling and would not function when there was no further change in acidity.

A number of clinical and experimental observations are consistent with the above hypothesis. Skeletal demineralization is a common finding in patients with chronic renal acidosis, with or without azotemia, although sometimes localized areas of increased skeletal density are also noted (9-11). Calcium lost from the skeleton is largely excreted in the stool of azotemic patients (12) and in the urine of those with the syndrome of renal tubular acidosis (8). Generalized demineralization of bone has also been reported in patients chronically acidotic after ureteroenterostomy (13). Ammonium chloride causes increased calciuria and phosphaturia (14) and, when given in large doses for prolonged periods to dogs, has been shown to produce skeletal decalcification (15). In further support of the concept that acidosis produces dissolution of bone is the generally accepted fact that correction of acidosis in patients with renal tubular acidosis arrests the progression of their 
bone disease $(8-10)$. On the other hand, it is stated that therapy with alkali alone does not restore calcium to bone in patients with uremic osteodystrophy $(9,10)$, but there have been no adequate long term studies of the effect of restoring and maintaining a normal plasma bicarbonate level in such patients.

Although there is thus much reason to suspect that acidosis may cause dissolution of bone, perhaps by a direcit effect of $\mathrm{pH}$ on the solubility of hydroxyapatite (16), it is likely that other factors, such as vitamin D resistance and secondary hyperparathyroidism, are also important $(9,10)$. The relation between acidosis and these other mechanisms remains to be elucidated. It is possible, for example, that the action of acidosis is mediated through changes in the metabolism or peripheral action of vitamin $\mathrm{D}$ or parathyroid hormone.

The present balance studies provide no information directly bearing on the possible release of skeletal salts during acidosis. Because of the brevity of the studies and the infrequency of stools, no significant data on calcium and phosphorus balance could be obtained. Clearly, it would be of interest in longer studies to compare the calcium balance during acidosis with that following correction of acidosis. It should be pointed out, however, that the external balance of calcium might not accurately reflect the extent to which dissolution of bone is occurring, since at least some of the calcium released from bone could be deposited in soft tissues.

Although we believe that neutralization of retained acid by dissolution of bone is the most attractive hypothesis to explain the present results, we must admit that some other alternatives have not been ruled out. It is possible that the fraction of the endogenous acid production not excreted in the urine is excreted from the body by some other route such as stool or sweat. It is also conceivable that the endogenous acid not excreted as urinary ammonium plus titratable acid is excreted in the urine conjugated with some unmeasured organic base that appears only in the presence of severe chronic acidosis. In the latter event, the abnormal mechanism for disposal of acid would not really be "extrarenal," but would represent a new form of renal acid excretion.
Setting aside speculation as to the exact nature of the mechanism for the disposal of the "retained" endogenous acid, what is the role of this process in the natural history of renal acidosis? In its absence, other compensatory factors might suffice to stabilize the degree of extracellular acidosis. As extracellular bicarbonate concentration falls, the net excretion of ammonium and titratable acid in the urine tends to rise, and in patients with relatively mild disease the urinary excretion of acid might ultimately become equal to acid production. Achievement of acid balance might also be facilitated by the self-selection of diets yielding relatively little net endogenous acid. However, in a patient with a given renal reserve and a given rate of endogenous acid production, the "extrarenal" mechanism for acid disposal probably helps to stabilize the extracellular bicarbonate at a level higher than would exist if such a process were not operative. Lacking such a mechanism, patients with severe renal impairment might not be able to stabilize their plasma hydrogen ion concentration before it fell to levels incompatible with life.

\section{Summary}

A new technique for the measurement of net external acid balance was applied to the study of patients with chronic renal acidosis. On a standard liquid formula diet patients with renal acidosis produced as much fixed acid as did normal subjects. During the development of renal acidosis in four patients, the acid balance was positive. The amount of acid retained was significantly greater than that required to produce the observed fall in extracellular bicarbonate, suggesting that some of the acid was buffered by intracellular base. In eight patients with chronic stable acidosis the acid balance was also positive. Approximately a third of the daily endogenous acid load failed to be excreted in the urine, yet extracellular bicarbonate did not change. When plasma bicarbonate was maintained at normal levels in six of these patients by the continuous administration of sodium bicarbonate, the positive acid balance was abolished in five.

The data indicate that acidosis in patients with renal disease calls into play an extrarenal mechanism that neutralizes the acid not excreted in the urine, and thereby helps to stabilize plasma bi- 
carbonate. The nature of this extrarenal mechanism is not revealed by these studies, but neutralization of acid by reaction with bone salts is an attractive hypothesis.

\section{References}

1. Schwartz, W. B., and A. S. Relman. Acidosis in renal disease. New Engl. J. Med. 1957, 256, 1184.

2. Elkinton, J. R. Hydrogen ion turnover in health and in renal disease. Ann. intern. Med. 1962, 57, 660.

3. Schwartz, W. B., P. W. Hall III, R. M. Hays, and A. S. Relman. On the mechanism of acidosis in chronic renal disease. J. clin. Invest. 1959, 38, 39.

4. Wrong, O., and H. E. F. Davies. The excretion of acid in renal disease. Quart. J. Med. 1959, 28, 259.

5. Elkinton, J. R., E. J. Huth, G. D. Webster, Jr., and R. A. McCance. The renal excretion of hydrogen ion in renal tubular acidosis. I. Quantitative assessment of the response to ammonium chloride as an acid load. Amer. J. Med. 1960, 29, 554.

6. Relman, A. S., E. J. Lennon, and J. Lemann, Jr. Endogenous production of fixed acid and the measurement of the net balance of acid in normal subjects. J. clin. Invest. 1961, 40, 1621.

7. Lennon, E. J., J. Lemann, Jr., and A. S. Relman. The effects of phosphoproteins on acid balance in normal subjects. J. clin. Invest. 1962, 41, 637.

8. Albright, F., and E. C. Reifenstein. The Parathyroid Glands and Metabolic Bone Disease. Baltimore, Williams \& Wilkins, 1948, p. 242.
9. Dent, C. E., C. M. Harper, and G. R. Philpot. Treatment of renal-glomerular osteodystrophy. Quart. J. Med. 1961, 30, 1.

10. Stanbury, S. W., and G. A. Lamb. Metabolic studies of renal osteodystrophy. I. Calcium, phosphorus and nitrogen metabolism in rickets, osteomalacia and hyperthyroidism complicating chronic uremia and in the osteomalacia of the adult Fanconi syndrome. Medicine (Baltimore) 1962, 41, 1.

11. Kaye, M., J. E. Pritchard, G. W. Halpenny, and W. Light. Bone disease in chronic renal failure with particular reference to osteosclerosis. Medicine (Baltimore) 1960, 39, 157.

12. Liu, S. H., and H. I. Chu. Studies of calcium and phosphorus metabolism with special reference to pathogenesis and effects of dihydrotachysterol (A.T. 10) and iron. Medicine (Baltimore) 1943, $22,103$.

13. Harrison, A. R. Clinical and metabolic observations on osteomalacia following ureterosigmoidostomy. Brit. J. Urol. 1958, 30, 455.

14. Martin, H. E., and R. Jones. The effect of ammonium chloride and sodium bicarbonate on the urinary excretion of magnesium, calcium and phosphate. Amer. Heart J. 1961, 62, 206.

15. Jaffe, H. L., A. Bodansky, and J. P. Chandler. Ammonium chloride decalcification, as modified by calcium intake: the relation between generalized osteoporosis and ostitis fibrosa. J. exp. Med. 1932, $56,823$.

16. Neuman, W. F., and M. W. Neuman. The Chemical Dynamics of Bone Mineral. Chicago, University of Chicago Press, 1958, p. 32.

\section{ANNOUNCEMENT OF MEETINGS}

The American Federation for Clinical Research will hold its Twentysecond Annual Meeting in Atlantic City, N. J., at the Casino Theater on the Steel Pier on Sunday, May 2, 1965, at 9:00 a.m. Joint sectional meetings with The American Society for Clinical Investigation will be held on Sunday afternoon at Chalfonte-Haddon Hall, and additional meetings sponsored by The American Federation for Clinical Research will be held on Sunday evening.

The American Society for Clinical Investigation, Inc., will hold its Fifty-seventh Annual Meeting in Atlantic City, N. J., on Monday, May 3, at 9:00 a.m., at the Casino Theater on the Steel Pier, and will join The American Federation for Clinical Research in simultaneous sectional meetings on Sunday afternoon, May 2, in Chalfonte-Haddon Hall.

The Association of American Physicians will hold its Seventy-eighth Annual Meeting in Atlantic City, N. J., at the Casino Theater on the Steel Pier on Tuesday, May 4, at 9:30 a.m., and in the Carolina Room, Chalfonte-Haddon Hall, on Wednesday, May 5, at 9:30 a.m. 